\title{
ガス透過性防水シートの耐久性評価 および接合部性能評価
}

\author{
西村正樹 1 - 赤井智幸 $2 \cdot$ 嘉門雅史 3
}

\begin{abstract}
埋め立ての終了した廃棄物最終処分場では, 閉鎖時に最終カバー層が設置される.この最終カバー層に用い るキャッピング材料として, 筆者らは, ガス透過性と遮水性を併せ持つ微多孔膜と, 微多孔膜を保護し施工而 性を付与寸る不織布から構成されるガス透過性防水シートを開発し，その適用性を評価してきた，本研究では， 勾配1:2.0の盛土斜面内で50 cm覆土下に埋設され，3年が経過したガス透過性防水シートについて，土中での経 年耐久性を評価した. また, 熱融着接合部の性能評価を行った. その結果, 斜面施工後 3 年が経過した状態で も, ガス透過性防水シートの基本性能である遮水性, ガス透過性, 力学特性が初期性能を維持していることが 確認された. さらに, このガス透過性防水シートは, 接合部の遮水性を保持しつつ現場での熱融着接合を可能 にするために，工場製造段階であらかじめ端部に加熱圧縮処理を施すが，この処理により，100 cmの水頭圧に 対しても接合部の遮水性が碓保できることがわかった.
\end{abstract}

キーワード : ガス透過性防水シート, 廃棄物最終処分場, キャッピング材料, 而久性, 接合部

\section{1.はじめに}

我が国では近年，一般廃棄物の $79 \%$ 程度が焼却処理 後に埋立処分されており ${ }^{1)}$, 廃棄物最終処分場（以下,

「処分場」と称す））には，バイオリアクターとしての 役割を期待するというよりも，重金属等の有害物質の漏 洩防止が重視されるべき状況に至っている ${ }^{2)}$. そのよう な背景の下，埋め立てが終了した処分場において閉鎖時 に設置される最終カバー層には, 廃棄物層への降水の浸 入を防止するとともに，廃棄物から発生するガスを適切 に排出する機能が必要とされる. 特に, 焼却残椬の埋立 てを主体とする処分場の閉鎖においては，浸出水による 環境污染リスクや, 浸出水処理に要するコストの低減が 大きな課題となっている. また，そのような処分場の閉 鎖時には, 廃棄物層の不特定位置でガスが発生しても, 速やかに排出できる面的なガス透過機能が重要であり, それらの要求機能を満たし, 最終カバー層に適用できる ジオシンセティックス製キャッピング材料 ${ }^{3), 4}$ が求めら れている.

筆者らはこれまで, ガス透過性と遮水性を併せ持つ微 多孔膜と, 微多孔膜を保護し施工而性を付与寸る不織布 から構成されるガス透過性防水シートを開発し, 種々の 室内実験・屋外実験によって, 基本性能ならびにキャッ ピング材料としての適用性を評価してきた ${ }^{5)-12) . ~ そ の ~}$ 中で, 2008 年 7 月以降, 勾配 1:2.0 の盛士斜面の覆土
下（層厚 : $50 \mathrm{~cm}$ ）にガス透過性防水シートを埋設して, 斜面安定性実証実験を実施し，シートおよびその上部の 覆土の安定性が確保できることを実証してきた ${ }^{11)}$.

ここで，斜面安定性実証実験に供したガス透過性防 水シートは，実際に工事で使用されて盛士斜面内に一定 期間埋設されたものと同等の材料履歴にあると考えられ, このような条件下の材料性能を適切に評価し, デー夕蓄 積を図ることは，材料の信頼性を検討寸る上で極めて有 益である. 本研究では, 斜面施工 3 年経過後に盛土斜 面からガス透過性防水シートを掘り出し, その主要性能 である遮水性, ガス透過性, および力学特性を調べるこ とで，土中での経年耐久性を評価した。

また，実際の処分場でのシート敷設時には，シート 同士の接合が不可欠である. したがって, 最終カバー層 としての遮水性を確保するためには，接合部の遮水性が 最も重要であるが, 開発したガス透過性防水シートは, 芯䩗繊維を素材とする不織布を用いることで，接合部に おいても高度な遮水性を保持し得る端部構造を有してい る. その遮水性能を評価するため, 自走式熱融着機を用 いた接合実験により熱融着接合し，接合部の透水実験を 行った. さらに，現場での接合部の品質管理に資するた め, 接合方向に垂直な方向に引張りせん断変形を加え, その破壊モードを観察するとともに，引張りせん断強さ （以下，「接合部強さ」と称す．）を測定した.

\footnotetext{
1正会員，地方独立行政法人大阪府立産業技術総合研究所 綫維・高分子科 主任研究員（广5941157 大阪府和泉市あゆ久野2-7-1）

2正会員，地方独立行政法人大阪府立産業技術総合研究所 䋊維・高分子科長（广594-1157 大阪府和泉市あゆみ野2-7-1）

3正会員, 国立香川高等専門学校 校長・ジオシンセティックス技術研究会 会長（†761-8058 香川県高松市勅使町355)
} 


\section{2. 実験方法}

\section{（1）ガス透過性防水シート}

本研究では，厚さ $100 \mu \mathrm{m}$ のポリエチレン製微多孔膜 の上下面に，ポリエステル/ポリエチレン芯鞘繊維製の ニードルパンチ長繊維不織布（単位面積あたりの質量 : $\left.300 \mathrm{~g} / \mathrm{m}^{2}\right)$ を貼り合わせ，積層させたガス透過性防水シ 一トを用いた．図-1 にガス透過性防水シートの断面構 造を模式的に示寸.

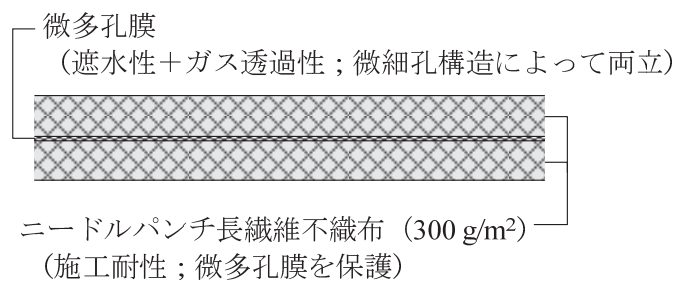

図-1ガス透過性防水シートの断面構造模式図

\section{（2）耐久性評価}

\section{a）盛土斜面からの試料採取}

斜面安定性実証実験での斜面施工（2008 年 7 月; 詳 細は既報参照 ${ }^{11)}$ ) から 3 年が経過した 2011 年 8 月に,

図-2 に示寸盛士斜面の 3 箇所 $(\mathrm{A} \sim \mathrm{C})$ からガス透過性 防水シートを掘り出し，試料を採取した. 図-3に試料 採取前の盛土斜面の状況を示寸. また，図-4 に試料採 取の状況を例示寸る. ただし，土中に埋設されていたた め, 採取した試料には土粒子が付着していたが，本研究

\section{【側面図】}

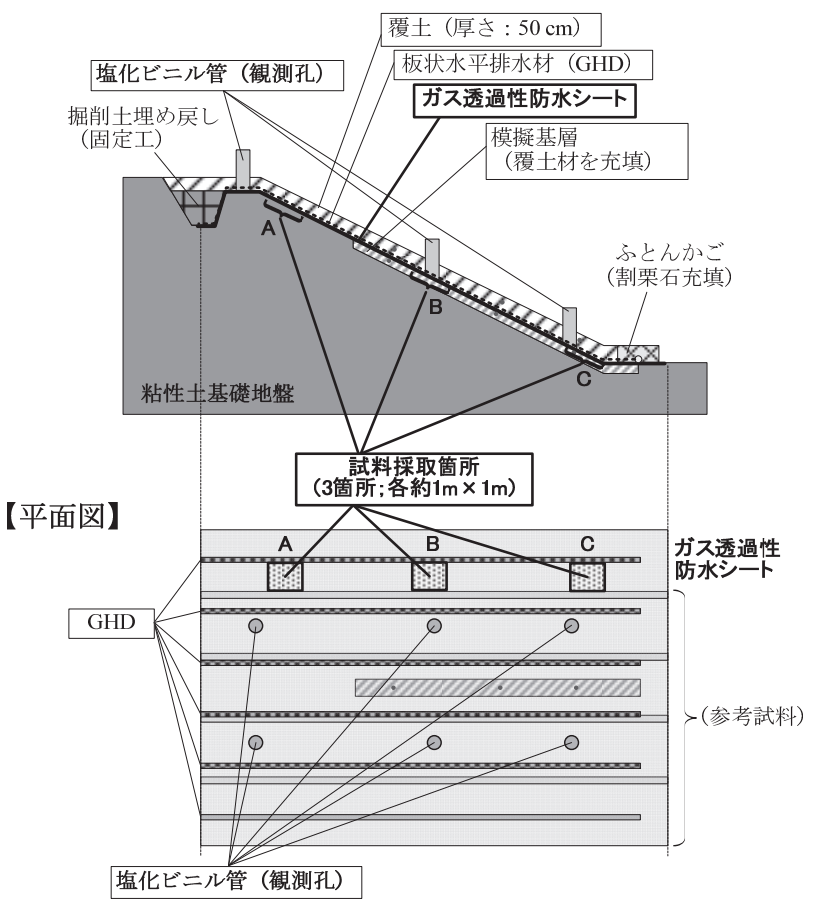

図-2 盛士斜面の断面模式図

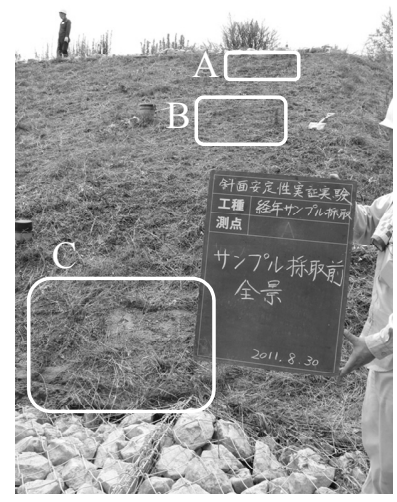

図-3 試料採取前の盛士斜面の状況

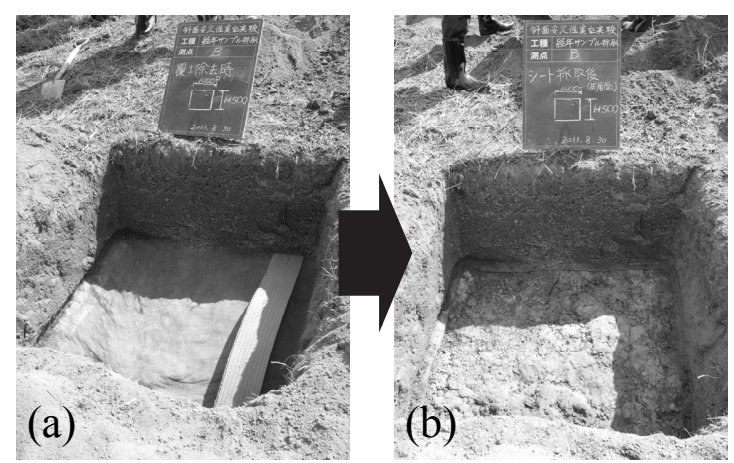

図-4 試料採取の状況（試料採取箇所 : B)

(a) 覆土撤去時, (b) ガス透過性防水シー卜採取後

では洗浄等による土粒子の除去は行わず，そのままの状 態で実験に供した。

\section{b）遮水性評価}

ガス透過性防水シートの遮水性は，而水度試験装置 （大栄科学精器製作所製 WP-5k）を用い，JIS L 1092

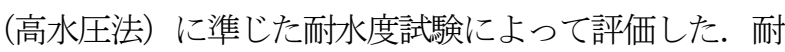
水度試験装置の主要部模式図を図-5 に示寸。試料の下 面に水圧を一定速度 $(1.67 \mathrm{kPa} / \mathrm{s})$ で上昇させつつ付加 し, 試料上面に水滴が漏出した際の水圧を耐水度として 計測した．ただし，実際にはガス透過性防水シートは土 中に埋設され，面的に拘束された状況下で使用されるこ とから, 耐水度試験においても, 試料の上面をステンレ スメッシュで保護し，水圧による試料の膨張を防止した.

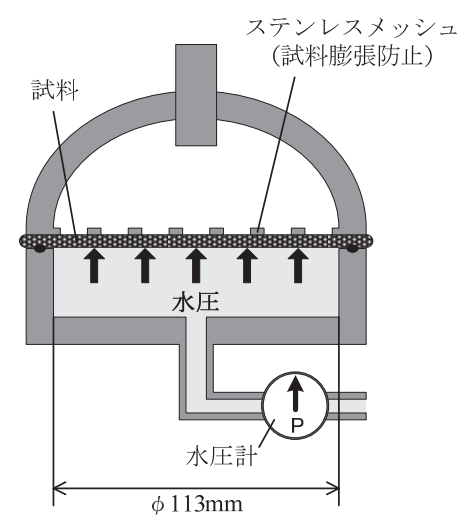

図-5 耐水度圾験装置の主要部模式図 
また, JIS L 1092 では, 試料面内の 3 箇所で水滴が確認 された時の水圧を耐水度としているが, ここでは, より 厳密な評価とするために, 水滴が 1 箇所で確認された 際の水圧を耐水度とし，3 回の試験の平均值により評価 した.

\section{c）ガス透過性評価}

ガス透過性防水シートにおけるガス透過メカニズムは, 濃度勾配に基づく拡散現象である ${ }^{5), 6)}$. そこで，JIS L 1099 に準じ, 水蒸気の拡散輸送量である透湿度によっ てガス透過性を評価した.

ここで，盛十斜面より採取したガス透過性防水シート には土粒子が付着しているので，シート自体の透湿度を 評価するためには，土粒子への水分の吸着を考慮しなけ ればならない，すなわち，土粒子一の水分吸着挙動が非 定常的であり，時間経過とともに吸着量が飽和するのに 対して, ガス透過性防水シートの透湿挙動は本来, 定常 的である. したがって，ガス透過性防水シートの透湿度 を適切に評価するためには，土粒子への水分吸着が飽和 に達した後に測定する必要がある.

JIS L 1099 においては, 図-6 に示寸 2 つの試験方法 が示されている.このうち A-1 法では, 吸湿剤として 塩化カルシウムが用いられ, 恒温恒湿装置内にカップを 静置して 1 時間後から 2 時間後の間のカップ重量の増 分から，透湿度が算定される. しかし，系が定常に達す るまでに時間を要するような場合は, 塩化カルシウム自 体の吸湿能もまた時間経過とともに低下してしまうので, A-1 法による評価は適さない，そこで，本研究では A-2 法を適用し，土粒子への水分吸着が飽和に達寸る $4 \sim 5$ 時間後の重量変化から透湿度を求め, 3 回の試験の平均 值により評価した。

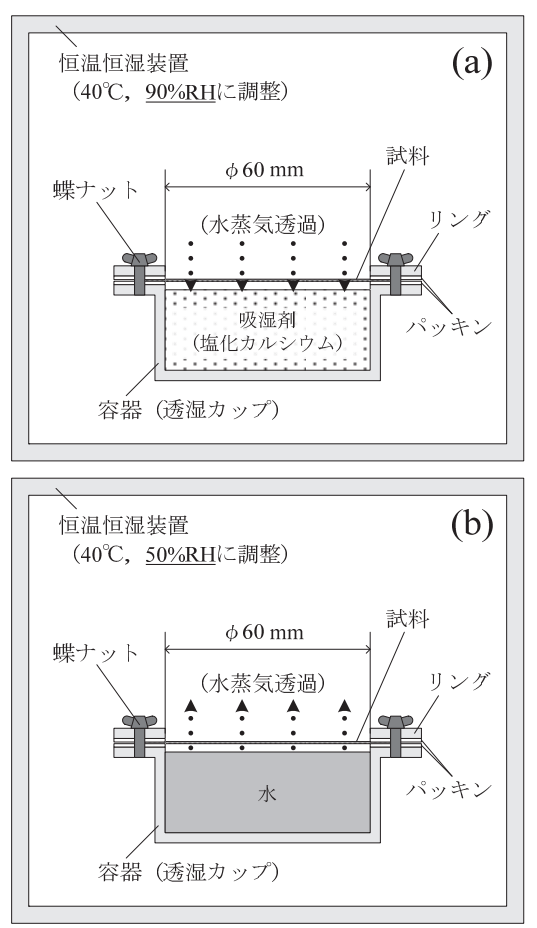

図-6 透湿度試験の模式図 (a) A-1 法, (b) A-2法

\section{d) 力学特性評価}

$10 \mathrm{kN}$ 材料試験機（島津製作所製 AG-10kNG）を用 いて引張り試験を行い，引張強さおよび伸び率を測定し た. JIS L 1908 に準じ，試料幅を 50 mm，つか夕間隔 を $100 \mathrm{~mm}$ ，引張り速度を $20 \mathrm{~mm} / \mathrm{min}$ (つか夕間隔の 20\%/min）とした. また， 5 回の試験の平均值により評 価を行った.

\section{（3）接合部性能評価}

\section{a) 接合実験}

図-1 に示したように，ガス透過性防水シートは，遮 水性を有する微多孔膜の上下に透水性の不織布を配した 構造となっている. よって, 接合部での漏水を防ぐため には，不織布の空隙を閉塞させ，その面内方向の通水を 遮断する必要がある。

開発したガス透過性防水シート（図一7）は，ポリエス テル/ポリエチレン芯鞘繊維を素材とする不織布を用い ており，工場でのシート製造段階で，端部に加熱圧縮加 工を施して芯䩗繊維のポリエチレン (䩗) 部分を選択的 に溶融・固化させることで，あらかじめ不織布層の空隙 を潰し，面内方向一の通水を遮断できる構造を有してい る. 本研究では，この端部同士を熱融着接合し，実験に 用いた．接合部の断面模式図を図-8に示寸.

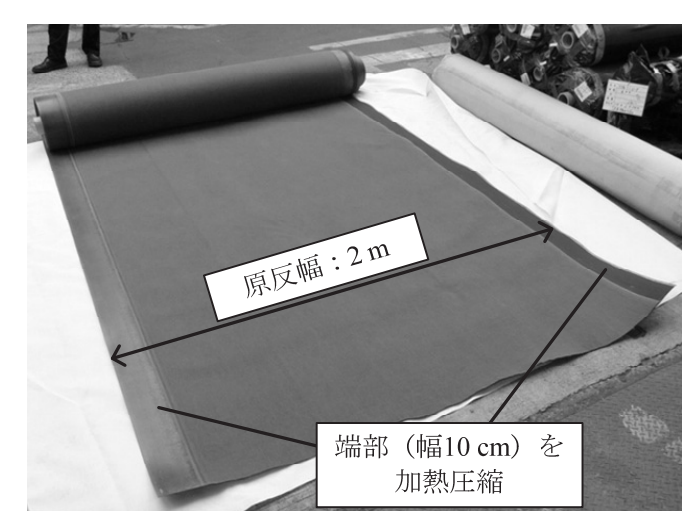

図-7＼cjkstart端部が加熱王縮処理されたガス透過性防水シート

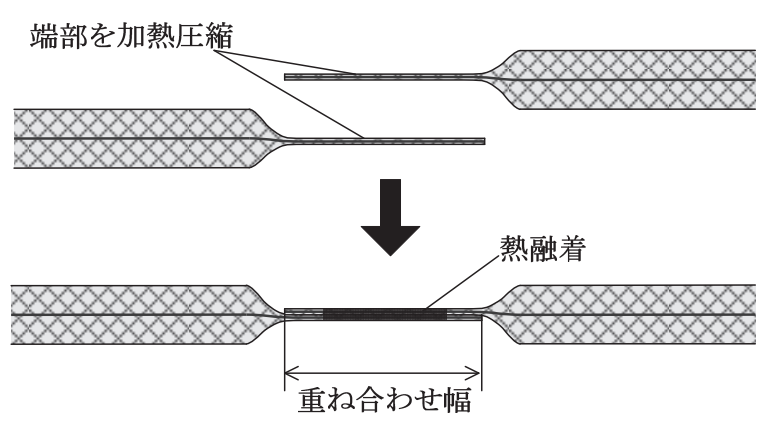

図-8 接合部の断面模式図

なお，上記の端部処理を施したガス透過性防水シー トによる接合実験に先立ち, 端部のみならずシート全面 を加熱圧縮処理したものを試作し（以下，「試作品」と 
称す。），それらについても接合実験を行った.

熱風吐出型の自走式熱融着機（LEISTER 社製 TWINNY）を用い，ガス透過性防水シートの接合実験 を行った. 自走式熱融着機の機構および外観を，それぞ れ図-9，図-10 に示す。自走式熱融着機による接合では， 重社合わせたガス透過性防水シート端部が熱風によって

【側面図】
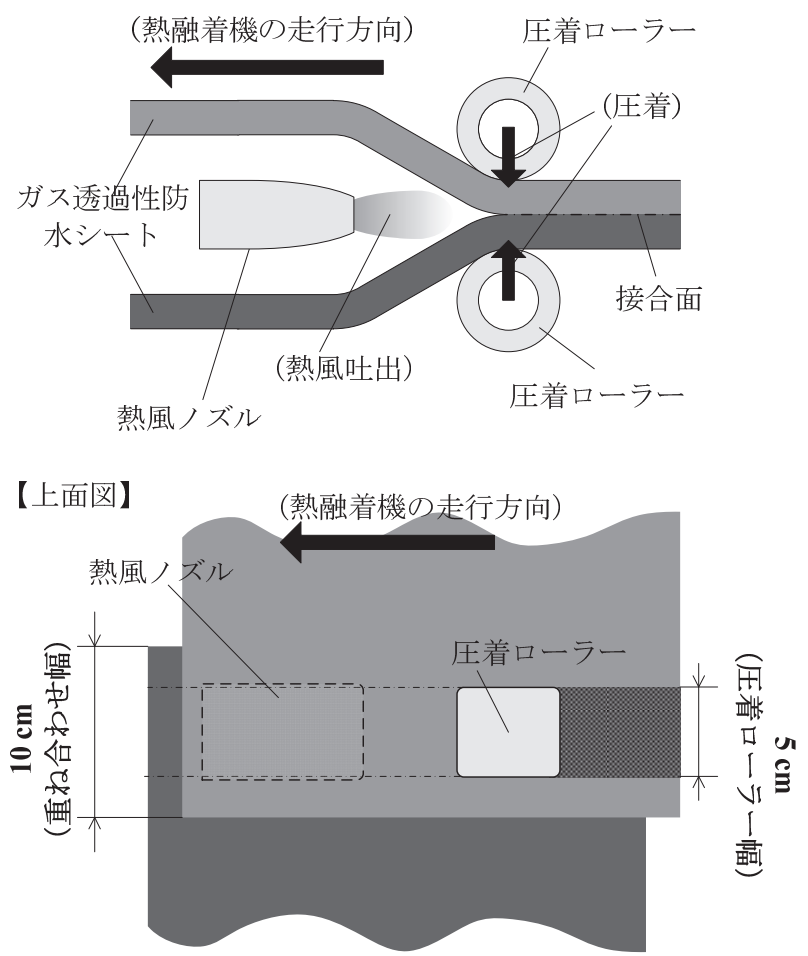

図-9 自走式熱融着機の機構

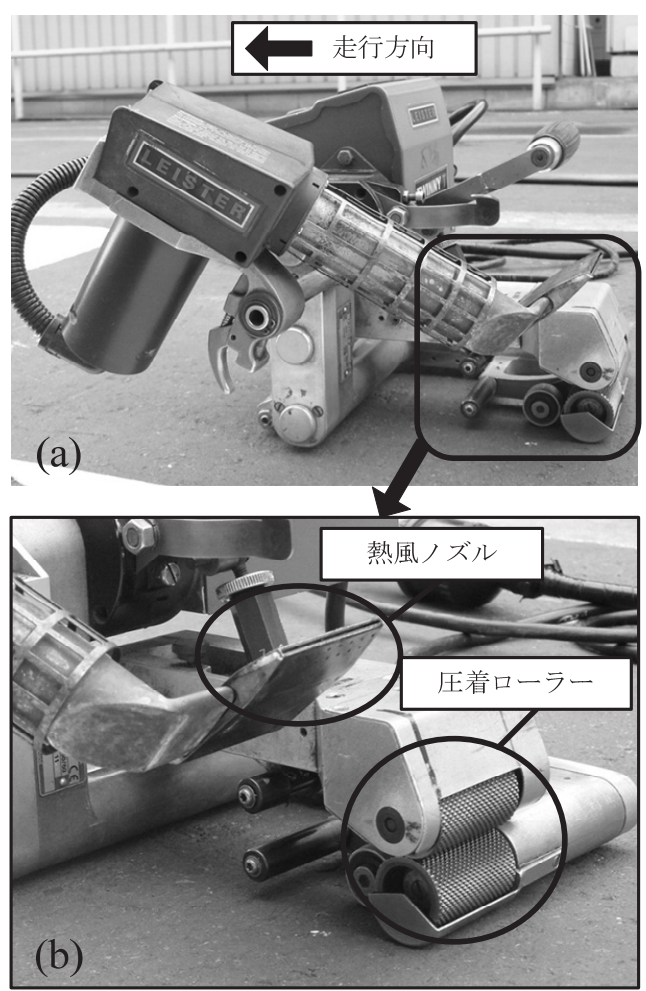

図-10 自走式熱融着機（a) 外観，(b) 主要部拡大
加熱，溶融されるとともに，圧着ローラーによって順次， 圧着される. 自走式熱融着機は接合方向に沿って一定ス ピードで走行するため，一定の条件下での接合が可能で ある.

接合実験の条件を表-1 に示寸。なお，自走式熱融着 機においては，熱風の温度を $10^{\circ} \mathrm{C}$ 間隔で設定できるが， これは機械内部での制御のための設定值であり，ノズル から吐出される熱風の温度は，気温等の影響を受ける. そこで，図-11 に示すように，ノズル先端の熱風吐出口 から $5 \mathrm{~mm}$ 離れた位置での熱風温度を測定・確認した.

表-1 接合実験の条件

\begin{tabular}{|c|c|c|c|c|}
\hline No. & $\begin{array}{l}\text { 気温 } \\
{\left[{ }^{\circ} \mathrm{C}\right]}\end{array}$ & $\begin{array}{c}\text { 設定温度 } \\
{\left[{ }^{\circ} \mathrm{C}\right]} \\
\end{array}$ & $\begin{array}{c}\text { 走行スピード } \\
{[\mathrm{m} / \mathrm{min}]}\end{array}$ & $\begin{array}{c}\text { 吐出口熱風温度 } \\
{\left[{ }^{\circ} \mathrm{C}\right]}\end{array}$ \\
\hline $1 *$ & \multirow{6}{*}{17} & 250 & 1.5 & 196 \\
\hline $2 *$ & & 300 & 3.0 & 256 \\
\hline $3 *$ & & 300 & 1.5 & 256 \\
\hline $4 *$ & & 400 & 1.5 & 284 \\
\hline $5 *$ & & 500 & 1.5 & 296 \\
\hline $6 *$ & & 560 & 1.5 & 330 \\
\hline 7 & \multirow{3}{*}{14} & 350 & 1.5 & 255 \\
\hline 8 & & 400 & 1.5 & 290 \\
\hline 9 & & 450 & 1.5 & 310 \\
\hline
\end{tabular}

* 試作品（シート全面を加熱圧縮処理）による実験

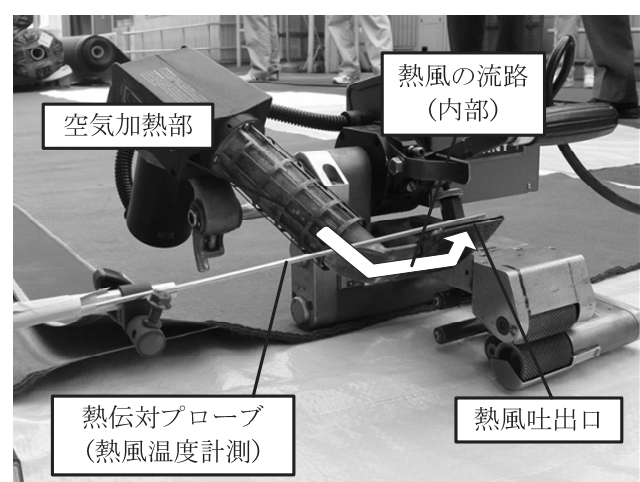

図-11＼cjkstart吐出口熱風温度の計測状況

\section{b) 接合部透水実験}

表-1 に示した 9 条件で作製した接合部試料に対して, JIS A 1218 を参照して透水試験をそれぞれ 3 回ずつ実 施し，遮水性を評価した。透水実験装置の模式図を図一 12 に示寸.

接合部が $\phi 30 \mathrm{~cm}$ の水圧付与面の中心を通るように試 料を配置し，試料の表面および裹面のパッキンと接する 面には，パラフィンおよびシリコーン系のコーキング剂 を含浸させることで，評価対象とする接合部以外からの 不要な漏水を防止した.

透水円筒に水を静かに投入し， $50 \mathrm{~cm}$ あるいは 100 $\mathrm{cm}$ の水頭圧を付与して静置した. 接合部からの透水が 認められた場合は，一定の水頭圧を確保しつつ，透水量 が概称安定するまで 1 時間ごとに透水量を計測し，安 定後の 3 回の測定值の平均から 1 時間あたりの透水量 $\left(V\left[\mathrm{~m}^{3} / \mathrm{h}\right]\right)$ を算出した。 さらに, $V$ を有効接合長 


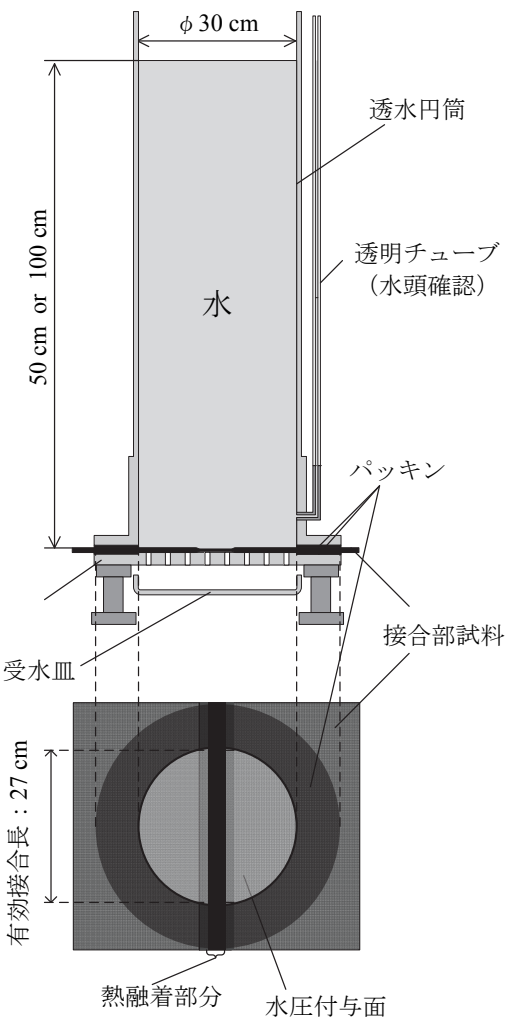

図-12 透水実験装置の模式図
$(L)$ で除して，単位接合長あたりの透水量（ $Q$ $\left.\left[\mathrm{m}^{3} / \mathrm{m} \cdot \mathrm{h}\right]\right)$ を求めた。一方, 24 時間経過後も透水が認 められなかったものは, $Q=0 \mathrm{~m}^{3} / \mathrm{m} \cdot \mathrm{h}$ と夕なし, 一部 についてはさらに静置し, 最大 50 日間, 継続して透水 状況を確認した.

\section{c）接合部の力学特性評価}

ガス透過性防水シートの接合部試料について, 実際 の施工現場で品質管理等に用いられる可搬型の簡易引張 り試験機（LEISTER 社製 Examo Tensiometer）を用い, 接合部の引張りせん断実験を行った. すなわち，接合方 向に垂直な方向に引張りせん断変形を加え，その破壊モ ードを確認するとともに，接合部強さを測定した．なお， 接合部強さは 3 回の試験の平均で評価した。 また, 簡
易引張り試験機の装置上の制約から, 試料片の幅は 25 $\mathrm{mm}$ とし, つか夕間隔 : $200 \mathrm{~mm}$, 引張り速度 : 100 $\mathrm{mm} / \mathrm{min}$ とした. 簡易引張り試験機による接合部の引張 りせん断実験の状況を図-13に示寸.

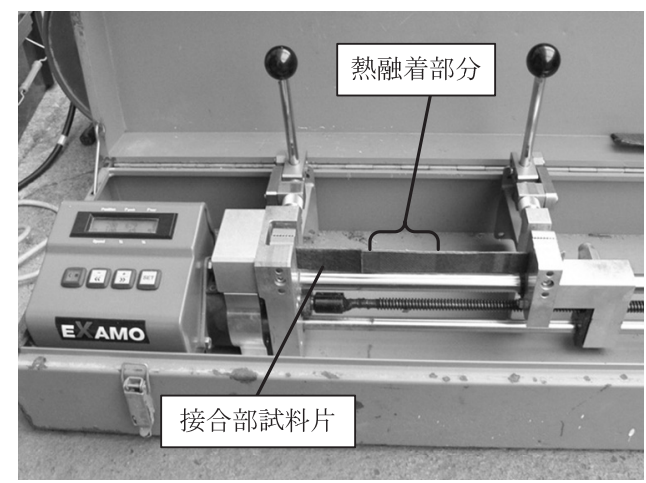

図-13 接合部の引張りせん断実験

\section{3. 結果と考察}

\section{（1）耐久性評価}

表-2 表-4 に, 斜面施工 3 年経過後の耐水度, 透湿 度, 引張強さおよび伸び率を初期性能と併せて示す.

表-2 斜面施工3年経過後の而水度

\begin{tabular}{|c|c|c|c|c||c|}
\hline \multicolumn{2}{|c|}{ 試料 No. } & 1 & 2 & 3 & 平均值 \\
\hline \multicolumn{2}{|c|}{ 初期性能 } & 473 & 455 & 484 & 471 \\
\hline \multirow{3}{*}{ 斜面施工3年経過後 } & A & 460 & 459 & 441 & 453 \\
\cline { 2 - 6 } & B & 455 & 448 & 427 & 443 \\
\cline { 2 - 6 } & $\mathrm{C}$ & 429 & 455 & 408 & 431 \\
\hline
\end{tabular}

表-3 斜面施工3年経過後の透湿度

\begin{tabular}{|c|c|c|c|c|c|}
\hline \multicolumn{2}{|l|}{ 試料 No. } & 1 & 2 & 3 & 平均値 \\
\hline \multicolumn{2}{|l|}{ 初期性能 } & 1693 & 1754 & 1825 & 1757 \\
\hline \multirow{3}{*}{ 斜面施工 3 年経過後 } & $\mathrm{A}$ & 1754 & 1992 & 2045 & 1930 \\
\hline & $\mathrm{B}$ & 1918 & 1848 & 1392 & 1719 \\
\hline & $\mathrm{C}$ & 1392 & 1968 & 1874 & 1745 \\
\hline
\end{tabular}

表-4 斜面施工3年経過後の引張強さおよび伸び率

\begin{tabular}{|c|c|c|c|c|c|c|c|c|c|}
\hline \multicolumn{4}{|c|}{ 試料 No. } & 1 & 2 & 3 & 4 & 5 & 平均值 \\
\hline \multirow{8}{*}{$\begin{array}{l}\frac{\sqrt{I}}{\mathbb{R}} \\
\underset{N}{N} \\
N^{\prime}\end{array}$} & \multirow{4}{*}{$\begin{array}{c}\text { 引張強さ } \\
{[\mathrm{kN} / \mathrm{m}]}\end{array}$} & \multicolumn{2}{|l|}{\begin{tabular}{|l} 
初期性能 \\
\end{tabular}} & 39.0 & 39.8 & 39.8 & 38.9 & 39.9 & 39.5 \\
\hline & & \multirow{3}{*}{ 斜面施工 3 年経過後 } & $\mathrm{A}$ & 38.4 & 38.3 & 38.1 & 39.6 & 38.7 & 38.6 \\
\hline & & & $\mathrm{B}$ & 38.7 & 39.5 & 39.9 & 37.8 & 39.2 & 39.0 \\
\hline & & & $\mathrm{C}$ & 39.7 & 38.6 & 39.0 & 37.7 & 37.2 & 38.4 \\
\hline & \multirow{4}{*}{$\begin{array}{c}\text { 伸び率 } \\
\text { [\%] }\end{array}$} & \multicolumn{2}{|l|}{ 初期性能 } & 75.9 & 78.4 & 78.6 & 78.3 & 77.0 & 77.6 \\
\hline & & \multirow{3}{*}{ 斜面施工 3 年経過後 } & $\mathrm{A}$ & 78.7 & 78.1 & 76.0 & 77.6 & 78.5 & 77.8 \\
\hline & & & $\mathrm{B}$ & 77.2 & 82.2 & 79.6 & 76.9 & 82.1 & 79.6 \\
\hline & & & $\mathrm{C}$ & 82.0 & 80.7 & 81.8 & 79.4 & 71.0 & 79.0 \\
\hline \multirow{8}{*}{$\begin{array}{l}\frac{\text { 恶 }}{2} \\
\text { if } \\
\text { 16 }\end{array}$} & \multirow{4}{*}{$\begin{array}{c}\text { 引張強さ } \\
{[\mathrm{kN} / \mathrm{m}]}\end{array}$} & \multicolumn{2}{|l|}{ 初期性能 } & 29.8 & 28.8 & 26.5 & 28.4 & 24.8 & 27.7 \\
\hline & & \multirow{3}{*}{ 斜面施工3年経過後 } & A & 26.1 & 30.6 & 28.7 & 29.8 & 28.7 & 28.8 \\
\hline & & & $\mathrm{B}$ & 28.1 & 29.3 & 29.3 & 28.4 & 28.8 & 28.8 \\
\hline & & & $\mathrm{C}$ & 26.3 & 29.8 & 28.9 & 29.2 & 30.1 & 28.9 \\
\hline & \multirow{4}{*}{$\begin{array}{c}\text { 伸び率 } \\
\text { [\%] }\end{array}$} & \multicolumn{2}{|l|}{ 初期性能 } & 78.4 & 76.1 & 79.6 & 78.6 & 72.1 & 77.0 \\
\hline & & \multirow{3}{*}{ 斜面施工3年経過後 } & $\mathrm{A}$ & 74.5 & 82.6 & 78.6 & 83.4 & 86.5 & 81.1 \\
\hline & & & $\mathrm{B}$ & 83.5 & 89.1 & 88.8 & 84.7 & 90.6 & 87.3 \\
\hline & & & $\mathrm{C}$ & 77.7 & 83.3 & 78.0 & 77.0 & 81.6 & 79.5 \\
\hline
\end{tabular}


表-2〜表-4 より, 耐水度, 透湿度, 引張強さおよび 伸び率は, いずれも初期性能と同等であり, 施工後 3 年が経過した状態でも，ガス透過性防水シートは初期性 能を維持していることが確認された。

なお，耐水度および透湿度に関し，ガス透過性防水 シートにおける遮水性とガス透過性の両立は，微多孔膜 の微細な孔構造によってもたらされる。このため，覆土 による荷重が継続的に作用することで，微細孔が著しく 拡大した場合，耐水度の低下が懸念される ${ }^{10), 12)}$ 。他方， 土粒子により微細孔が閉塞し，透湿度が低下寸る可能性 もある。しかし，両性能に関し，そのような著しい性能 低下が認められなかったことから，微多孔膜にはガス透 過性防水シ一トの性能に影響を及ぼすような孔構造の変 化は生じていなかったと推察される。一方，ガス透過性 防水シートにおける力学特性は不織布のそれにほぼ由来 していると言えること ${ }^{10)}$, 斜面施工 3 年経過後も引張 強さおよび伸び率が初期性能と同等であったことから， 不織布にも大きな変状はなかったと考えられる.

ここで，キャッピング材料として適用する場合，ガ 又透過性防水シートの上部には，層厚が概称 $50 \mathrm{~cm}$ の 覆土が設置される ${ }^{13)}$ 。よって，覆土が飽和に達した場 合，才なわち，ガス透過性防水シートに $50 \mathrm{~cm}$ 程度の 水頭圧が作用した場合でも，遮水性が確保できることが 必要となる. よって，ガス透過性防水シートには最低限， $5 \mathrm{kPa}$ 以上の耐水度が要求されるが，表-2 に示したとお り，施工後 3 年が経過した状態でも，母材部ではこれ よりも 2 桁弱大きな耐水度が確保できている.

また，ガス透過性に関して，焼却残渣の埋め立てを 主体と寸る処分場におけるガス発生量 ${ }^{14)}$ から, 廃棄物 層の平均深さを $20 \mathrm{~m}$ と仮定し，単位面積あたりの水蒸 気発生質量に換算すると, 数十 $\mathrm{g} / \mathrm{m}^{2} \cdot 24 \mathrm{~h}$ のオーダー となる．したがって，このガス発生量に対応可能な透湿 度として，100 g/ $\mathrm{m}^{2}$ ・24h 以上の透湿度が必要であると 考えられる.これに対して，表-3 に示した透湿度は 1
桁以上大きな值を示しており，ガス透過性に関しても， キャッピング材料として十分な性能を有していると言え る.

なお，廃棄物最終処分場において保護マットとして 用いられる長繊維不織布には, $18.5 \mathrm{kN} / \mathrm{m}$ 以上の引張強 さが要求される ${ }^{15)}$ が，ガス透過性防水シートは，斜面 施工 3 年経過後もそれ以上の值を示している.

\section{（2）接合部性能評価}

接合部透水試験および接合部の引張りせん断実験の 結果を，それぞれ，表-5，表-6 示す．また，接合部の 引張りせん断実験における破壊モードを図-14 に模式的 に示す．ただし，表-6の母材における数值は，接合部 試料と同条件で母材の引張り試験を行った際の引張強さ である。

表-5，表-6 および図-14 より，接合界面において適切 な溶融，一体化が実現できていたもの，すなわち，引張 りせん断変形付与時に接合部界面での剥離が発生しなか ったものは，100 cm の水頭圧を最大 50 日間，継続して 付与させた場合でも，接合部からの漏水は認められなか った。よって，芯鞘繊維の特長を活かした独自の端部加 熱王縮処理を施すことで，適切な熱融着接合条件の下， $100 \mathrm{~cm}$ の水頭圧に対しても接合部の遮水性が確保でき ることが確認された。

なお，接合部以外の母材部にも水圧が付与されてい ることから，表-5における $Q=0 \mathrm{~m}^{3} / \mathrm{m} ・ \mathrm{~h}$ は，母材部 から加熱圧縮処理された端部，熱融着部分に至るいずれ の水圧付与部でも, 漏水が発生していないことを示して いる. さらに，表-2 に示した耐水度の評洒結果も考え 合わせると, $50 \mathrm{~cm}$ 覆土 ${ }^{13)}$ が降水によって飽和状態に なったとしても，その下に埋設されるガス透過性防水シ 一トに関しては，接合部を含めた面的な遮水性を確保で きると言える.

また，引張りせん断実験における破壊モードが「接

表-5＼cjkstart接合部透水実験の結果

\begin{tabular}{|c|c|c|c|c|c|c|c|c|}
\hline \multirow{4}{*}{ No. } & \multicolumn{8}{|c|}{ 単位接合長あたりの透水量 $Q\left[\mathrm{~m}^{3} / \mathrm{m} \mathrm{h}\right]$} \\
\hline & \multicolumn{4}{|c|}{$50 \mathrm{~cm}$ 水頭圧付与時 } & \multicolumn{4}{|c|}{$100 \mathrm{~cm}$ 水頭圧付与時 } \\
\hline & \multicolumn{3}{|c|}{ 試料 No. } & \multirow{2}{*}{ 平均值 } & \multicolumn{3}{|c|}{ 試料 No. } & \multirow{2}{*}{ 平均値 } \\
\hline & 1 & 2 & 3 & & 1 & 2 & 3 & \\
\hline $1 *$ & 0.00059 & 0.00067 & 0.00064 & 0.00066 & 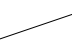 & 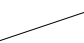 & 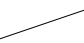 & 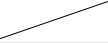 \\
\hline $2 *$ & 0.0017 & 0.0015 & 0.0016 & 0.0016 & 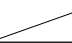 & $r$ & 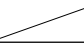 & 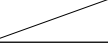 \\
\hline $3 *$ & 0 & 0 & 0 & 0 & 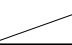 & 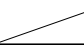 & 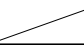 & 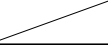 \\
\hline $4 *$ & 0 & 0 & 0 & 0 & 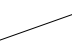 & $\infty$ & $\infty$ & 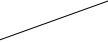 \\
\hline $5 *$ & 0 & 0 & 0 & 0 & 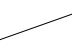 & 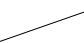 & 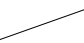 & 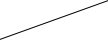 \\
\hline $6 *$ & 0 & 0 & 0 & 0 & 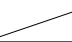 & & 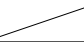 & 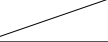 \\
\hline 7 & 0 & 0 & 0 & 0 & 0 & 0 & 0 & 0 \\
\hline 8 & 0 & 0 & 0 & 0 & 0 & 0 & 0 & 0 \\
\hline 9 & 0 & 0 & $0 * *$ & 0 & 0 & 0 & $0 * * *$ & 0 \\
\hline
\end{tabular}

* 試作品（シート全面を加熱圧縮処理）による実験

** $\quad$ 週間継続して確認

*** 50日間継続して確認 
表-6＼cjkstart接合部の引張りせん断実験結果

\begin{tabular}{|c|c|c|c|c|c|}
\hline \multirow{3}{*}{ No. } & \multicolumn{4}{|c|}{ 接合部強さ [kN/m] } & \multirow{3}{*}{ 破壊モード } \\
\hline & \multicolumn{3}{|c|}{ 試料 No. } & \multirow{2}{*}{ 平均值 } & \\
\hline & 1 & 2 & 3 & & \\
\hline $1 *$ & 26.3 & 23.8 & 23.8 & 24.6 & \multirow{2}{*}{ 接合部界面で剥離 } \\
\hline $2 *$ & 20.4 & 21.5 & 24.0 & 22.0 & \\
\hline $3 *$ & 30.8 & 34.9 & 32.6 & 32.8 & \multirow{2}{*}{ 接合部外で破断 } \\
\hline $4 *$ & 32.6 & 31.5 & 30.8 & 31.6 & \\
\hline $5 *$ & 28.6 & 27.0 & 25.8 & 27.1 & \multirow{2}{*}{ 圧着ローラー走行端部で破断 } \\
\hline $6 *$ & 27.2 & 22.9 & 28.8 & 26.3 & \\
\hline 7 & 25.6 & 23.5 & 25.4 & 24.8 & \multirow{3}{*}{ 接合部外で破断 } \\
\hline 8 & 25.4 & 25.1 & 27.2 & 25.9 & \\
\hline 9 & 24.9 & 24.9 & 25.2 & 25.0 & \\
\hline 母材 ${ }^{* *}$ & 26.8 & 28.1 & 26.2 & 27.0 & \\
\hline $\begin{array}{l}* \\
* *\end{array}$ & $\begin{array}{l}\text { 式作品 } \\
\text { 司条件 }\end{array}$ & |張 & こおけ & $\begin{array}{l}\text { 理）に } \\
\text { 張強さ }\end{array}$ & \\
\hline
\end{tabular}

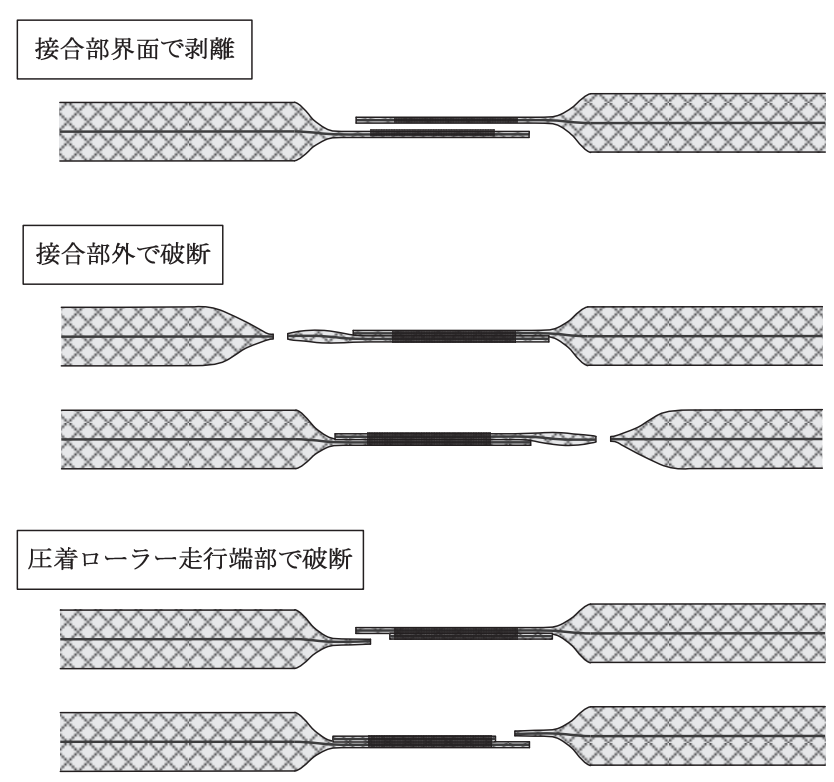

図-14 接合部の破壊モード模式図

合部外で破断」あるいは「圧着ローラー走行端部で破 断」であり，且つ，接合部強さが母材の引張強さの 90\%以上あれば，遮水性の高い接合部が得られることが わかった. よって，実際の施工現場においては，簡易引 張り試験機を用いて接合部の引張りせん断試験を実施し, その破壊モードならびに接合部強さを確認することで, 現場での品質管理が可能である. なお, 接合条件 3〜5 において，接合部強さが母材の引張強さを上回ったが, シート全面を加熱圧縮処理した試作品を用いたためであ ると推察される.

\section{4. まとめ}

ガス透過性と遮水性を併せ持つ微多孔膜と, 微多孔膜
を保護し施工而性を付与する不織布から構成されるガス 透過性防水シートについて，盛土斜面で50 cm覆士下に 3年間埋設されたシートを採取し，遮水性，ガス透過性， および力学特性を評価した。 その結果, 斜面施工後3年 が経過した状態でも，遮水性に係る耐水度，ガス透過性 に係る透湿度, 力学特性に対応する引張強さおよび伸び 率は，それぞれ初期性能を維持していることが確認され た.

また，開発したガス透過性防水シートは，特殊な繊 維を素材とする不織布を用いるとともに，工場製造段階 で端部に加熱圧縮処理を施すことで，あらかじめ端部に おける不織布層の空隙を潰し, 面内方向への通水を遮断 できる構造である. この構造により, 自走式熱融着機に よる接合部において，100 cm水頭下でも遮水性を確保 できることがわかった，さらに，接合部の遮水性と引張 
りせん断実験時の破壊モードは密接に関連しており，実 際の施工現場においては，簡易引張り試験機を用いて接 合部の引張りせん断試験を実施し，その破壊モードなら びに接合部強さを確認することで，現場での接合部の品 質管理が可能である.

謝辞 : 本研究に多大なご協力を頂きましたジオシンセテ イックス技術研究会 ガス透過性防水シートキャッピン グ工法グループのメンバー各位に深謝の意を表します.

\section{参考文献}

1) 環境省大臣官房廃棄物・リサイクル対策部 廃棄物対策課 : 日本の廃棄物処理 平成22年度版，環境省，p. 6，2012。

2) R. M. Koerner and D. E. Daniel : 廃棄物処分場の最終カバ 一, 嘉門雅史監訳 /勝見武，近藤三二共訳，技報堂出版， p. ii, 2004.

3) 国際ジオシンセティックス学会日本支部 ジオメンブレン技 術委員会 : ごみ埋立地の設計施工ハンドブックーしや水工 技術一，オーム社，pp. 119-122，2000.

4）廃棄物最終処分場跡地形質変更に係る基準検討委員会 : 最 終処分場跡地形質変更に係る施工ガイドライン，環境省， pp. $3.52-3.53,2006$.

5) 西村正樹，赤井智幸，和田昭太，楠部義夫，嘉門雅史 : 廃 棄物処分場キャッピング用複合シートの機能評価と施工而 久性評価, ジオシンセティックス論文集, 第 21 巻, pp. 285-290, 2006.

6) M. Nishimura, T. Akai, K. Negishi, M. Ishida, S. Wada, Y. Nambu, and M. Kamon: Characteristics and construction durability on hybrid geosynthetics for capping of landfill site, Proc. of the 7th Japanese-Korean-French Seminar On
Geo-Environmental Engineering, pp. 85-91, 2007.

7) 西村正樹，赤井智幸，和田昭太，楠部義夫，浅田毅，嘉門 雅史 : 土中に敷設された廃棄物最終処分場キャッピング用 複合シートのガス透過性実証実験，ジオシンセティックス 論文集，第22巻，pp. 133-138， 2007.

8) M. Nishimura, T. Akai, and M. Kamon: Gas permeability of hybrid geosynthetics for landfill cap cover, Geosynthetics in Civil and Environmental Engineering (Proc. of the 4th Asian Regional Conf. on Geosynthetics), pp. 552-558, 2008.

9) 西村正樹, 赤井智幸, 嘉門雅史 : 廃棄物最終処分場キャッ ピング用ジオコンポジットの摩擦特性評価, ジオシンセテ イックス論文集，第23巻，pp. 247-252， 2008.

10) 西村正樹, 赤井智幸, 嘉門雅史 : 廃棄物最終処分場キャッ ピング用ジオコンポジットにおける不織布の保護性能，J. of Textile Engineering, Vol. 55, No. 5, pp. 129-137, 2009.

11) 西村正樹，赤井智幸，和田昭太，新開千弘，浅田毅，嘉門 雅史 : 廃棄物最終処分場キャッピング用ジオコンポジット の斜面部への適用に関する研究，ジオシンセティックス論 文集，第24巻，pp. 31-36，2009.

12) 西村正樹，赤井智幸，嘉門雅史 : 廃棄物最終処分場キャッ ピング用ジオコンポジットの引張り変形時における遮水性 評価，ジオシンセティックス論文集，第25巻，pp. 241$246,2010$.

13) 総理府令・厚生省令 : 一般廃棄物の最終処分場及び産業廃 棄物の最終処分場に係る技術上の基準を定める命令の一部 を改正する命令，第1条 2 十七，1998.

14) 田中信壽 : 環境安全な廃棄物埋立処分場の建設と管理，技 報堂出版, pp.75-76, 2000.

15) 社団法人全国都市清掃会議 : 廃棄物最終処分場整備の計 画・設計・管理要領 2010改訂版, pp.641-643， 2010.

\title{
DURABILITY AND CHARACTERISTICS ON SEAM OF GAS-PERMEABLE/WATERPROOF SHEET FOR LANDFILL CAP COVER
}

\author{
Masaki NISHIMURA, Tomoyuki AKAI and Masashi KAMON
}

\begin{abstract}
Landfill cap cover that simultaneously suppresses water infiltration to the waste and promotes rapid gas permeation is demanded. We have developed gas-permeable/waterproof sheet (GPWS), comprising a micro-porous sheet which is waterproof but have gas permeability, coated with nonwovens to protect it, and investigated characteristics and applicability of GPWS as a landfill cap cover. In this study, durability and characteristics on seam of GPWS were evaluated. Results showed that waterproof, gas permeability, and tensile properties of GPWS, which has been laid in test slope for 3 years, remained their original level. In addition, it was demonstrated that water impermeability in seam of GPWS can be achieved under $100 \mathrm{~cm}$ hydraulic head.
\end{abstract}

KEYWORDS: Gas-Permeable/Waterproof Sheet, Landfill, Cap Cover, Durability, Seam 